\title{
Population density and reproduction of two Peruvian leaf-eared mice (Phyllotis spp.)
}

\author{
Densidad poblacional y reproducción de dos ratones orejudos del Perú (Phyllotis spp.)
}

\author{
MARGARITA ARANA, OSWALDO RAMÍREZ1, SERGIO SANTA MARÍA, CESAR KUNIMOTO, RODRIGO VELARDE, \\ CECILIA DE LA CRUZ \& MARÍA LUISA RUÍZ
}

\author{
Departamento de Ciencias Biológicas y Fisiológicas, Facultad de Ciencias, Universidad Peruana \\ Cayetano Heredia, Avenida Honorio Delgado 430, Urbanización Ingeniería, \\ San Martín de Porres, Lima, Perú; e-mail1: oramirez@upch.edu.pe
}

\begin{abstract}
Population density and reproduction were studied in two leaf-eared mice (Phyllotis spp.) in the Peruvian locality known as Lomas de Lachay. Density varied between 0-3 individuals ha $^{-1}$ in $P$. andium, and between 0-12 individuals ha ${ }^{-1}$ in $P$. amicus. An annual cycle of population abundance was observed in both species. Phyllotis amicus showed no seasonal reproductive activity, but $P$. andium had seasonal reproduction with pregnant females principally observed between July and September. Differences in juvenile weight were related to litter size. It is likely that two young was the optimal litter size in the harsh and seasonal xeric environment of Lomas de Lachay. Our results suggest that $P$. amicus maintains low, highly dispersed populations in a harsh environment, and can reproduce at any time of the year, whereas $P$. andium appears to be a more irruptive species closely tied to rainfall patterns.
\end{abstract}

Key words: ecology, Phyllotis, rodents, population, desert.

\section{RESUMEN}

La densidad poblacional y reproducción de dos ratones orejudos (Phyllotis spp.) fueron estudiadas en la localidad peruana Lomas de Lachay. La densidad varió entre 0-3 individuos ha $\mathrm{a}^{-1}$ en $P$. andium, y entre 0-12 individuos ha ${ }^{-1}$ en $P$. amicus. En ambas especies se observaron cambios poblacionales que sugieren la existencia de ciclos anuales en la abundancia poblacional. El patrón reproductivo en las dos especies de Phyllotis fue claramente distinto. Phyllotis amicus mostró una actividad reproductiva no estacional, mientras que $P$. andium tuvo una reproducción estacional observándose hembras preñadas principalmente entre julio y septiembre. La diferencia en el peso de los juveniles estuvo relacionada con el tamaño de la camada. Es probable que en las Lomas de Lachay el tamaño de camada óptimo sea de dos individuos. Nuestros resultados sugieren que $P$. amicus es una especie que mantiene poblaciones bajas, altamente dispersas en áreas desérticas, y que puede reproducirse durante todo el año; mientras que $P$. andium parece ser una especie que irrumpe más en ambientes arbustivos dependientes de patrones de precipitación pluvial.

Palabras clave: ecología, Phyllotis, roedores, población, desierto.

\section{INTRODUCTION}

Leaf-eared mice (genus Phyllotis, Sigmodontinae) are one of the most abundant small mammals in the Peruvian Andes. Eight of 13 species inhabit this area, where a predominance of xeric habitats exists with sparse vegetation (Pearson 1958, Steppan 1995, 1998). Ecological studies of the Peruvian species of Phyllotis are scarce and reproduction data have been only occasionally reported. Two species of leaf-eared mice $(P$. amicus and $P$. andium) can be found in a unique seasonal habitat, the Lomas of Lachay, located on the central coast of Peru, $105 \mathrm{~km}$ north of Lima. Here, we present information on population density, movements, and reproduction (in natural and captive conditions) for these mice species.

\section{MATERIAL AND METHODS}

The fieldwork was done in the Teatinos pass, located on the western side of the Lachay National

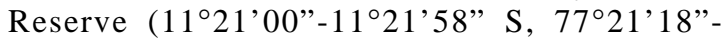
$\left.77^{\circ} 22^{\prime} 25^{\prime \prime} \mathrm{W}\right)$. Mean annual precipitation in the last four years (1998-2001) was 0.88, 0.29, 0.41, and $0.42 \mathrm{~mm}$, respectively. One 1-ha grid (altitude: $420 \mathrm{~m}$ ) with 81 trap stations ( $9 \times 9,10$-m intervals, one trap per station) was censused monthly from June 2000 to December 2001. A second (altitude: 
$350 \mathrm{~m}$ ), similarly-sized grid was censused between November 2000 and December 2001. Baited Sherman traps were placed at stations immediately before sunset and checked the following morning for two consecutive days each month. Animals were marked by toe clipping and released at the point of capture. Sex, reproductive condition, weight, and grid station were recorded. Traps were closed during the daytime. Population abundance was determined by the capture-markrecapture method using the Lincoln-Petersen index as modified by Chapman (1951). In order to study movements, we analyzed the location of consecutive captures of individuals through time, and the maximum time between first and last capture. Movement distance (minimum distance between the two furthest points of capture) also was calculated.

Reproductive activity of both Phyllotis species was assessed from examination of captured animals inside and outside grids. In addition, individuals of both species of Phyllotis (captured outside grids) were kept and bred in captivity. Each animal was housed in small cages $30 \mathrm{x} 18 \mathrm{x}$ $13 \mathrm{~cm}$ using wood shavings and paper as bedding materials. Animals were fed with fresh carrots, lettuce, sweet potato, sprouted wheat, and corn. Water was not provided to the animals after the first months as they never drank. Animals were maintained at an average temperature of $23 \pm 5$ ( \pm SD) ${ }^{\circ} \mathrm{C}$. For reproduction, one male was placed in a large cage $(36 \times 32 \times 20 \mathrm{~cm})$ for at least two days before introduction of the female. Pairs were maintained together for two weeks, after which the females were returned to small cages whereas the males were maintained in the large cages until a new mate was introduced. Animals were checked daily to record births and deaths in the colony. To analyze the effect of litter size on the weight of young, we recorded body weight each 10-20 days for 90 or more days after birth. Regression analyses between weight versus age were conducted for each litter size. Homogeneity of slopes were tested, and analyses of covariance were conducted to test for statistical differences $(\mathrm{P}<0.05)$ among the regressions.

\section{RESULTS}

Population densities of both Phyllotis species are shown in Fig. 1. Very small numbers of individuals per ha were observed during almost the entire study. Only $P$. amicus in the low grid showed a higher population density (12.3 individuals ha ${ }^{-1}$ ) between May and July of 2001. Phyllotis andium was more abundant in the high grid than in the low grid, and exhibited the highest numbers between July and August of 2000. Six P. amicus individuals were recaptured for more than three months and one for eight months. Using data from these individuals, movement distances varied between 22.8 and $78.8 \mathrm{~m}(\bar{X}=44.5 \pm 17.9 \mathrm{~m})$. Only one $P$. andium individual was recaptured one month later. Using the three $P$. andium individuals captured at least two times in the same month, the movement distance between captures varied between 40.8 and $68.8 \mathrm{~m}(\bar{X}=50.5 \pm 12.9 \mathrm{~m})$.

In captivity, 76 and 12 matings were conducted between individuals of $P$. andium and $P$. amicus, respectively. Twenty litters with a total of 45 young were obtained in $P$. andium, whereas four litters with eight young were obtained in $P$. amicus. The gestation time in both species was 24 days. Litter size varied between one and four young in $P$. andium and between one and three pups in Phyllotis amicus. Fig. 2 shows the number of pregnant females captured in Lomas de Lachay
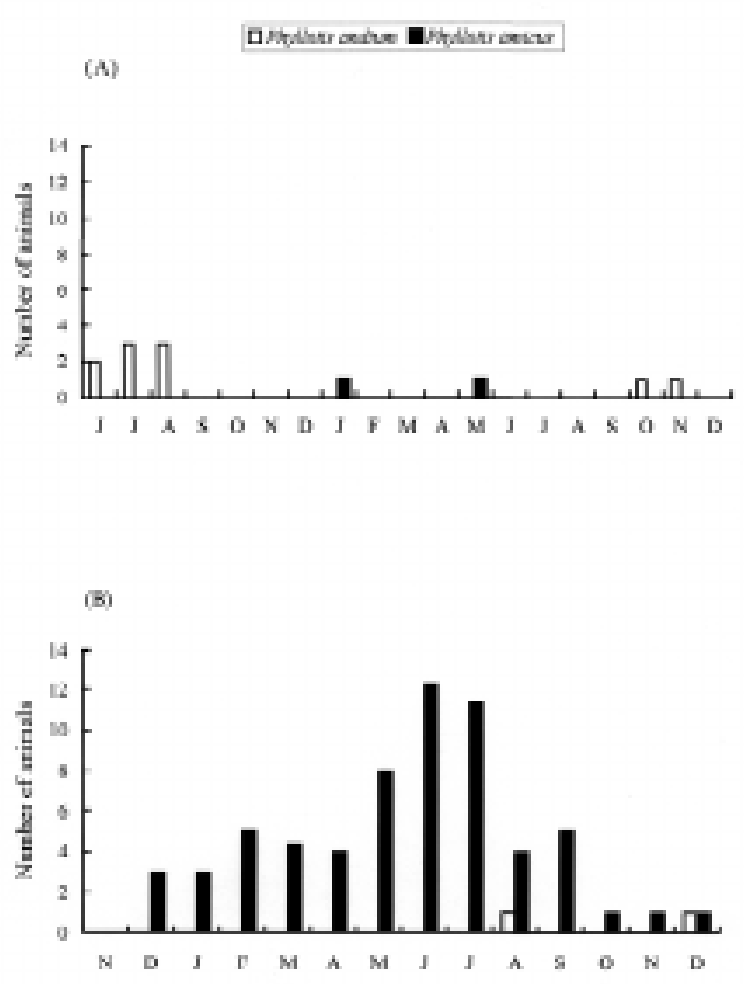

Fig. 1: Variation in the population density of Phyllotis andium and P. amicus. For each species two grids were examined: (A) June 2000 December 2001, and (B) November 2000 December 2001.

Variación en la densidad poblacional de Phyllotis andium y $P$. amicus. Se estudiaron dos cuadrantes para cada especie: (A) Junio 2000 - diciembre 2001, y (B) noviembre 2000 diciembre 2001 . 

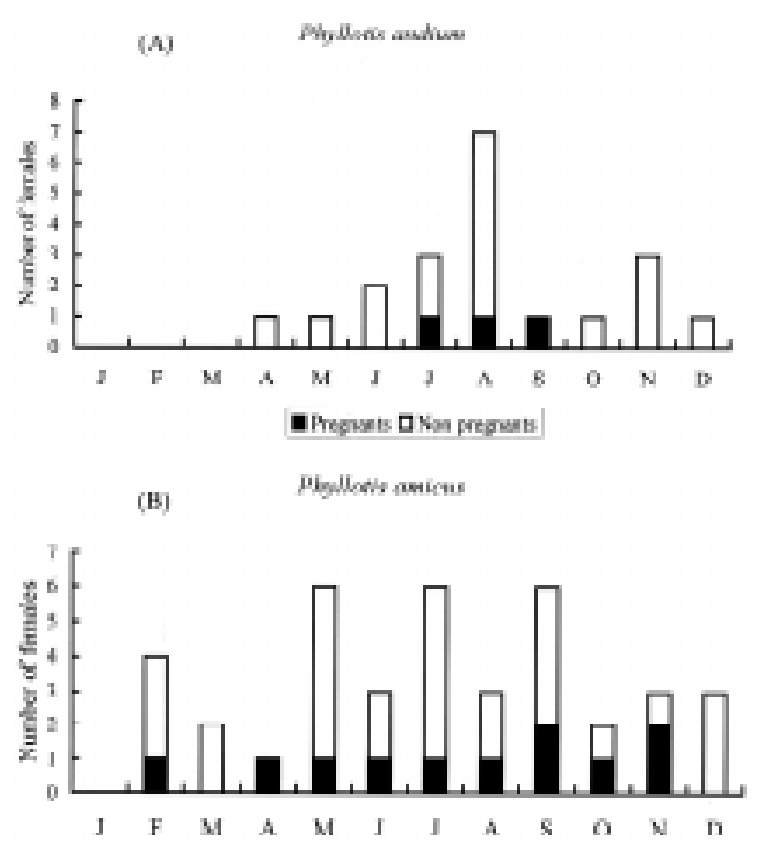

Fig. 2: Number of pregnant females captured in Lachay lomas by month. The black portion of the bars show the number of pregnant females and the white portion shows the number of non pregnant females.

Número de hembras preñadas capturadas mensualmente en las lomas de Lachay. La parte negra de las barras indica el número de hembras preñadas y la parte blanca muestra el número de hembras no preñadas. each month. Phyllotis amicus showed no seasonal reproduction, with pregnant females throughout the year. In contrast, $P$. andium showed clear seasonal reproductive activity between July and September. In the laboratory, $35 \%$ of female $P$. andium that became pregnant had litters with two young, whereas 30, 20 and $15 \%$ had litters of one, four and three young, respectively. An ANCOVA showed significant differences in the regressions between weight and age with different litter size (Fig. 3), indicating a relationship between weight and litter size. Heavier animals were from litters of one young whereas smaller animals came from litters with four young. Young (irrespective of litter size) were weaned 30 days after birth. Mean weight of young at weaning was $14.4 \pm 2.6 \mathrm{~g}$. Young reached mean weights of $17 \pm 3.4$ and 20.8 $\pm 4.7 \mathrm{~g}$ during their second and third months of life, respectively. In captivity, females less than seven months of age were not reproductively active.

\section{DISCUSSION}

This is the first report on the population ecology of two species of leaf-eared mice in the Lomas de Lachay, and the second that comes from Peruvian lomas (Péfaur et al. 1979, Pearson 1975). Pearson \& Ralph (1978) monitored Phyllotis limatus in a 2.02-ha grid in a loma near Tacna, 1,200 km south of Lima. They found that the population density

TABLE 1

Movement distances and length of residence of Phyllotis amicus and Phyllotis andium

Distancia de desplazamiento y tiempo de residencia de Phyllotis amicus y Phyllotis andium

\begin{tabular}{|c|c|c|c|c|}
\hline Species & Sex & $\begin{array}{l}\text { Movement } \\
\text { distance }(\mathrm{m})\end{array}$ & $\begin{array}{l}\text { Number of } \\
\text { captures }\end{array}$ & $\begin{array}{l}\text { Length of } \\
\text { residence (days) }\end{array}$ \\
\hline \multirow[t]{6}{*}{ Phyllotis amicus } & & 29.60 & 5 & 245 \\
\hline & & 22.80 & 6 & 91 \\
\hline & & 43.20 & 4 & 122 \\
\hline & & 50.40 & 5 & 127 \\
\hline & & 78.80 & 6 & 157 \\
\hline & & 42.00 & 3 & 100 \\
\hline \multirow[t]{3}{*}{ Phyllotis andium } & & 40.80 & 4 & 37 \\
\hline & & 68.00 & 3 & 3 \\
\hline & 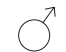 & 42.00 & 3 & 3 \\
\hline
\end{tabular}




\section{- Litter size 1 Litter size 2 - - - Litter size 3 - - - Litter size 4}

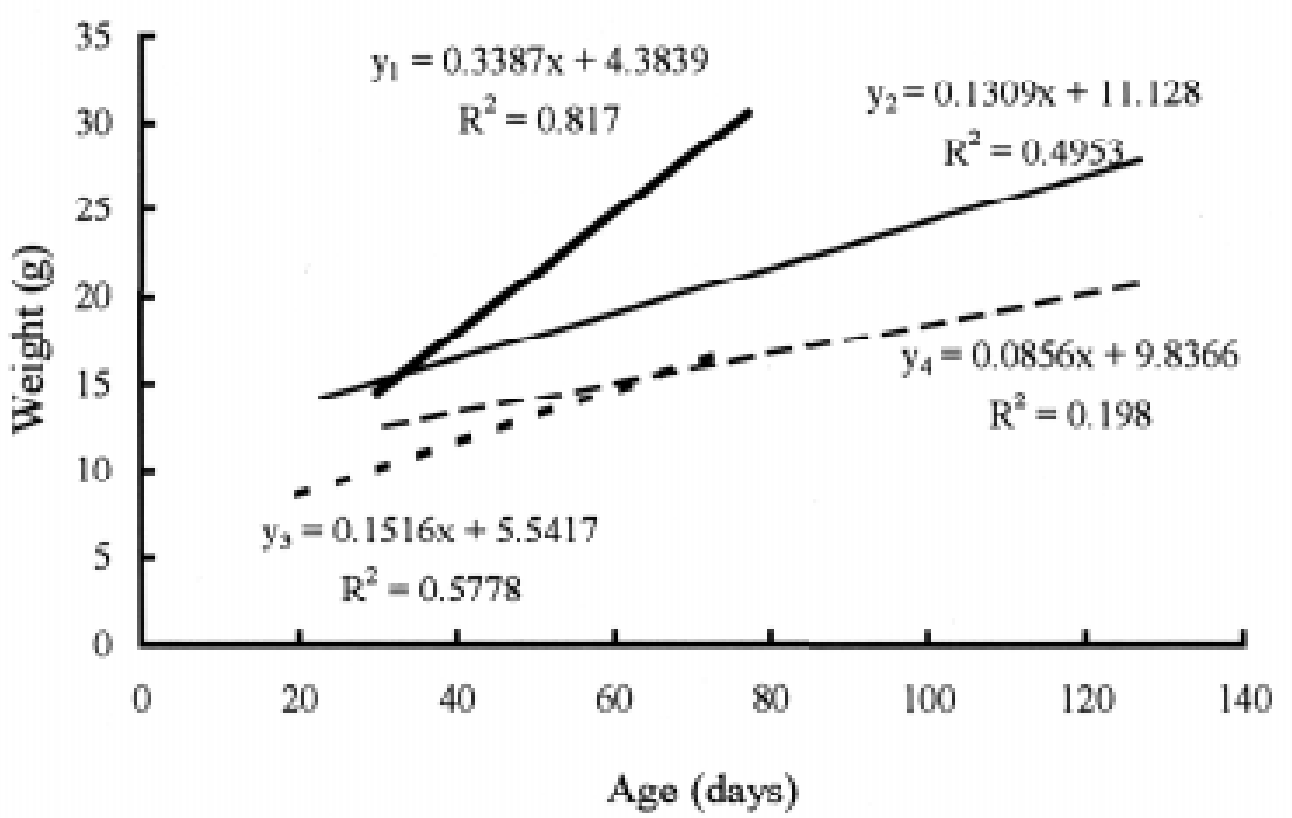

Fig. 3: Regression lines between weight and age for different litter size in $P$. andium.

Regresión lineal entre peso y edad en camadas de diferentes tamaños de $P$. andium.

was 6.5 individuals ha $\mathrm{a}^{-1}$, but considered this value to be an overestimate because the study occurred in November when the breeding season was ending and many young Phyllotis were in the population. After excluding these young, the population density was 3.9 individuals $\mathrm{ha}^{-1}$. Our results with $P$. andium and $P$. amicus showed similar values of density and suggest an annual cycle (Fig. 1), a pattern that has been previously reported for several South American rodents (Crespo et al. 1970, González et al. 1982, Murúa 1983, Murúa \& González 1985, Murúa \& González 1986, Murúa et al. 1986). Higher population densities were observed during the wet season (June-August) in both species. One interesting feature was the absence of individuals of $P$. andium during most of the study period in both grids. When traps were placed in other areas of Lomas de Lachay, the result for $P$. andium followed the same trend observed in the grids. Therefore, only occasional individuals appear to be present in the lomas except between July and August when their numbers increase. Captures of $P$. amicus outside of the grids were very low, and the individuals trapped were always in the most xeric and sparse habitats at low elevations in Lomas de Lachay. This suggests some spatial segregation between these two species of Phyllotis. Phyllotis andium occupies most of the area when in low numbers whereas $P$. amicus occurs in more restricted, xeric areas in the lowest parts of Lomas de Lachay. This segregation agrees with findings of Pizzimenti \& De Salle (1980) who also captured $P$. amicus isolated from its congeners. Both species of Phyllotis had nocturnal activity, and showed an aggregated distribution throughout the year suggesting a rather social type of spatial organization, which could be the result of some limiting factors such as substrate or shelter.

Mean distances traveled were 44.5 and $50.5 \mathrm{~m}$ for $P$. amicus and $P$. andium, respectively. Pearson $\&$ Ralph (1978) found a movement distance of 36 $\mathrm{m}$ for P. limatus at Morro Sama, a loma in southern Peru. Although this value is within the range of distances recorded in $P$. amicus $(22.8-78.8 \mathrm{~m})$ and close to the minimum value found in $P$. andium (40.8 and $68.8 \mathrm{~m}$ ), it is likely an underestimate due to the grid being trapped for only six nights in Morro Sama. Nevertheless, these results suggest that Phyllotis spp. restrict their movements in lomas-type ecosystems.

Reproductive activity differed between the two species of Phyllotis (Fig. 2). Pregnant females of $P$. andium were found mainly between July and September, whereas pregnant females of $P$. amicus were found throughout the year. These results 
suggest that $P$. andium reproduce seasonally and that breeding coincides with the wet period (winter; with precipitations above to $1.0 \mathrm{~mm}$ monthly). Phyllotis amicus lacked seasonal reproductive activity. A similar result was found by Williams (1990), who captured two pregnant $P$. amicus females in Lomas de Lachay during May and September. Differences between the reproductive patterns of $P$. andium and $P$. amicus may be related to their food habits. Although both species have broadly omnivorous feeding habits, $P$. amicus eats more insects that any other species of Phyllotis (Pizzimenti \& De Salle 1980), and therefore, this species may have a reproductive activity with a lesser dependence on vegetation. This finding is relevant due to the higher population density of $P$. amicus during May and July, which does not seem to be due to juvenile recruitment. One untested hypothesis is that mobility increases in the population, as it had been reported in other sigmodontine rodents (Murúa \& González 1986).

Differences in the weight of juveniles born in captivity are related to the litter size as shown in Fig. 3. Young from a litter of 1-2 individuals reach a higher weight in less time, thus likely increasing their survival rate. This suggests that there is a balance between the number and survivorship of young (as measured by growth and weight). Since the majority of pregnant $P$. andium females had a litter size of two, such figure could be the optimal litter size under the regular climatic conditions at Lomas de Lachay. However, during anomalous climatic conditions when food resources are over abundant (i.e., after El Niño Southern Oscillations, ENSO events), outbreaks of some Phyllotis species may occur (Pearson 1975, Jaksic et al. 1977, Péfaur et al. 1979, Meserve et al. 1995, Lima et al. 1999a, 1999b). Meserve et al. (1995) reported a dramatic increase in the population size of $P$. darwini in north-central Chile as a consequence of the 19911992 ENSO event. The population size of this species never exceeded 9 individuals $0.56 \mathrm{ha}^{-1}$ between 1989 and 1991, but reached a maximum of 25 in February 1992 and of 39 in May 1993. On the other hand, $P$. darwini reached 200 individuals ha ${ }^{1}$ during summer 1988 in Aucó, north-central Chile (Lima et al. 1999a, 1999b). Given that P. darwini is capable of producing many litters within a short period of time (Meserve \& Le Boulengé, 1987), and that the litter size in this species varies between 4.2 (Walker et al. 1984) and 5.2 (Fulk 1975, Meserve \& Le Boulengé 1987), the rapid increase of population size during an outbreak ("ratada") indicates that Phyllotis spp. have a reproductive potential largely constrained by environmental factors. Therefore, in a xeric, harsh, seasonal environment such as lomas ecosystems, a small litter size of two provides greater survival potential than larger litter sizes (4-6).

Our results showed no reproductive activity of females younger than seven months in $P$. andium. This may explain the relatively delayed response in the population changes of Phyllotis as a biological effect of ENSO events (Pearson 1975, Pefaur et al. 1979, Meserve et al. 1995). Other recent reports have suggested an interaction between delayed density-dependent factors and rainfall at demographic and population dynamic levels as the key element for understanding outbreaks of $P$. darwini in semiarid regions of Chile (Lima et al. 1999a, 1999b, Lima \& Jaksic 1999a, 1999b). Our short-term study did not allow us to evaluate this hypothesis in the species here studied.

The apparent year-around reproduction of $P$. amicus (in contrast to $P$. andium) and its very low population level may be a strategy that enables this species to persist in the lomas regardless of environmental conditions. Indeed, our results suggest that $P$. amicus is a species that maintains low, highly dispersed populations in a harsh environment, and can reproduce at any time of year, whereas $P$. andium appears to be a more irruptive species closely tied to rainfall patterns.

\section{ACKNOWLEDGMENTS}

This research was supported in part by a grant from the Red Impacto Biológico El Niño (RIBEN) / Concejo Nacional de Ciencia y Tecnología (CONCYTEC). We thank to David Velarde, Chief of Lachay National Reserve and his personal for giving us logistic facilities during the field work and precipitation data. We are very grateful to Peter Meserve for his comments and suggestions on this article.

\section{LITERATURE CITED}

CHAPMAN DG (1951) Some properties of the hypergeometric distribution with applications to zoological sample censuses. University of California Publications Statistics 1: 131-160.

CRESPO JA, MS SABATTINI, MJ PIANTANIDA \& G DE VILLAFAÑE (1970) Estudios ecológicos sobre roedores silvestres. Observaciones sobre densidad, reproducción y estructura comunitaria de roedores silvestres en el sur de Córdoba. Comisión Nacional de Estudio y Lucha contra la Fiebre Hemorrágica Argentina, Ministerio de Bienestar Social, Secretaría de Salud Pública, Buenos Aires, Argentina. 45 pp. 
FULK GW (1975) Population ecology of rodents in the semiarid shrublands of Chile. Occasional Papers, The Museum, Texas Tech University 33: 1-40.

GONZÁLEZ LA, R MURÚA \& R FEITO (1982) Densidad poblacional y padrones de actividad espacial de Akodon olivaceus (Rodentia, Cricetidae) en hábitats diferentes. In: Salinas P (ed) Actas de Séptimo Congreso Latinoamericano de Zoología, Zoología Neotropical: 935-947. Mérida, Venezuela.

JAKSIC FM, SI SILVA, PL MESERVE \& JR GUTIÉRREZ (1997) A long-term study of vertebrate predator responses to an E1 Niño (ENSO) disturbance in western South America. Oikos 78: 341-354.

LIMA M \& FM JAKSIC (1999a) Population rate of change in the leaf-eared mouse: the role of densitydependence, seasonality and rainfall. Australian Journal of Ecology 24: 110-116.

LIMA M \& FM JAKSIC (1999b) Population dynamics of three Neotropical small mammals: time series models and the role of delayed density-dependence in population irruptions. Australian Journal of Ecology 24: 25-34.

LIMA M, JE KEYMER \& FM JAKSIC (1999a) El NiñoSouthern Oscillation-driven rainfall variability and delayed dependence cause rodent outbreaks in western South America: linking demography and population dynamics. American Naturalist 153: 476-491.

LIMA M, PA MARQUET \& FM JAKSIC (1999b) El Niño events, precipitation patterns, and rodent outbreaks are statistically associated in semiarid Chile. Ecography 22: 213-218.

MESERVE PL \& ER LE BOULENGÉ (1987) Population dynamics and ecology of small mammals in the northern Chilean semiarid region. In: Patterson BD \& RM Timm (eds) Studies in Neotropical mammalogy: essays in honor of Philip Hershkovitz. Fieldiana: Zoology 39: 413-431.

MESERVE PL, JA YUNGER, JR GUTIÉRREZ, LC CONTRERAS, WB MILSTEAD, BK LANG, KL CRAMER, S HERRERA, VO LAGOS, SI SILVA, EL TABILO, MA TORREALBA \& FM JAKSIC (1995) Heterogeneous responses of small mammals to an El Niño Southern Oscillation event in northcentral semiarid Chile and the importance of ecological scale. Journal of Mammalogy 76: 580-595.

Associate Editor: F. Jaksic

Received March 26, 2002; accepted August 21, 2002
MURÚA R (1983) Dinámica de los números en Akodon olivaceus brachiotis (Rodentia: Cricetidae). Medio Ambiente (Chile) 6: 12-18.

MURÚA R \& LA GONZÁLEZ (1985) A cycling population of Akodon olivaceus (Cricetidae) in a temperate rain forest in Chile. Acta Zoológica Fennica 173: 77-79.

MURÚA R \& LA GONZÁLEZ (1986) Regulation of number in two Neotropical rodent species in southern Chile. Revista Chilena de Historia Natural 59: 193200.

MURÚA R, LA GONZÁLEZ \& PL MESERVE (1986) Population ecology of Oryzomys longicaudatus philippii (Rodentia:Cricetidae) in southern Chile. Journal of Animal Ecology 55: 281-293.

PEARSON OP (1975) An outbreak of mice in the coastal desert of Peru. Mammalia 39: 375-386.

PEARSON OP (1958) A taxonomic revision of the rodent genus Phyllotis. University of California Publications in Zoology 56: 391-496.

PEARSON OP \& CP RALPH (1978) The diversity and abundance of vertebrates along an altitudinal gradient in Peru. Memorias del Museo de Historia Natural "Javier Prado" 18: 1-97.

PÉFAUR JE, JL YÁÑEZ \& FM JAKSIC (1979) Biological and environmental aspects of a mouse outbreak in the semi-arid region of Chile. Mammalia 43: 313-322.

PIZZIMENTI JJ \& R DE SALLE (1980) Dietary and morphometric variation in some Peruvian rodent communities: the effect of feeding strategy on evolution. Biological Journal of the Linnean Society 13: 263-285.

STEPPAN S (1995) Revision of the tribe Phyllotini (Rodentia: Sigmodontinae), with a phylogenetic hypothesis for the Sigmodontinae. Fieldiana: Zoology 80: $1-112$.

STEPPAN S (1998) Phylogenetic relationships and species limits within Phyllotis (Rodentia: Sigmodontinae): concordance between mtDNA sequence and morphology. Journal of Mammalogy 79: 573-593.

WALKER LI, AE SPOTORNO \& J ARRAU (1984) Cytogenetic and reproductive studies of two nominal subspecies of Phyllotis darwini and their experimental hybrids. Journal of Mammalogy 65: 220-230.

WILLIAMS M (1990) Notas sobre reproducción de Phyllotis amicus Thomas (Rodentia: Cricetidae) en el campo y laboratorio. Biota (Perú) 96: 9-17. 